\title{
Effect of Metal lons and Surfactants on the Enzymatic Hydrolysis of Pretreated Lignocellulose
}

\author{
Yawen Zhou, Jian Yang, Cong Luo, Bo Yang, Changyao Liu, and Baocai Xu * \\ The effect of metal ions and surfactants on the enzymatic hydrolysis of \\ pretreated wheat straw lignocellulose was investigated. Scanning \\ electron microscopy, infrared spectrum analysis, dynamic light scattering, \\ and fluorescence spectra analysis were used to characterize the \\ influence of $\mathrm{Fe}^{3+}$ / polyoxyethylene (20) sorbitan monooleate (Tween 80). \\ The interaction between $\mathrm{Fe}^{3+} /$ Tween 80 and enzyme was further \\ investigated by enzyme kinetics and enzyme activity measurements. The \\ best synergistic effect was obtained when the ratio of $\mathrm{Fe}^{3+}$ and Tween 80 \\ was 0.06 . The scanning electron microscopy images showed that the \\ $\mathrm{Fe}^{3+} / \mathrm{T}$ ween 80 combination was associated with high porosity substrates. \\ The infrared spectrum analysis indicated that the components of the \\ substrates depended on additive types. The highest relative enzymatic \\ activity increase rate was obtained with added $\mathrm{Fe}^{3+} /$ Tween 80 . The $V_{\max }$ \\ and $K_{m}$ values of the group with added $\mathrm{Fe}^{3+} /$ Tween 80 were much higher \\ than that of the group without additives. With the addition of $\mathrm{Fe}^{3+} /$ Tween \\ 80 , the intensity of the fluorescence emission peak decreased and the \\ peak shifted towards a longer wavelength.
}

Keywords: Surfactants; Metal ions; Cellulose; Enzymatic hydrolysis

Contact information: School of Food and Chemical Engineering, Beijing Engineering and Technology

Research Center of Food Additives, Beijing Higher Institution Engineering Research Center of Food Additives and Ingredients, Beijing Technology \& Business University, No. 11 Fucheng Road, Beijing 100048, P. R. China; *Corresponding author: xubac@163.com

\section{INTRODUCTION}

The development of natural, environmentally friendly, renewable, and clean energy as a potential substitute for fossil energy is urgently needed for human society. Biomass energy is the largest renewable energy in the world, second only to fossil energy (Li 2007). Therefore, effective transformations of renewable biomass resources into usable energy have helped in beginning to solve the global energy crisis and have become a hot topic in the field of biomass. Enzymatic hydrolysis has been employed as the major method for the conversion of lignocellulose into fermentable sugar because of its advantages (Kristensen et al. 2007; Paljevac et al. 2007; Fang et al. 2010). Aiming at improving hydrolytic efficiency and reducing costs, extensive work has been carried out on this method.

For instance, metal ions have been introduced into cellulose pretreatment and enzymatic hydrolysis processes. Numerous studies have attempted to understand the application of metal ions in pretreatment (Liu and Wyman 2006; Liu et al. 2009a; Liu et al. 2009b; Chen et al. 2010; Zhao et al. 2011; Kamireddy et al. 2013; Kang et al. 2013). Recently, there has been an increasing interest in the role of metal ions in the enzymatic hydrolysis process (Liu et al. 2011; Ren et al. 2012; Li et al. 2015; Wang et al. 2018). However, the effect of metal ions on enzymatic hydrolysis depends on cation and 
cellulose substrate types, along with many other factors. Therefore, the need to achieve a deeper understanding of metal ion effect remains an important issue in this area.

Aiming at reducing ineffective adsorption of lignin by enzyme (Eriksson et al. 2002; Börjesson et al. 2007), addition of surfactants may remarkably improve the cellulose enzymatic hydrolysis efficiency. Anionic (Lou et al. 2013, 2014a,b), nonionic (Tu and Saddler 2010; Sun et al. 2011), and cationic (Monschein et al. 2014) surfactants have been employed for different substrates. Among these surfactants, a series of nonionic surfactants, the polysorbates, have shown great efficiency. For example, the addition of polysorbate 20 into mixed cellulase hydrolysate largely improved the conversion rate of enzymatic hydrolysis of wheat straw (Luo and Liu 2011).

The effect of metal ions and surfactants on enzymatic hydrolysis depends on many factors, including cellulose substrate type and enzymolysis conditions. For further improvement, detailed investigations into the effects of metal ions and surfactants are essential. Although the effects of inorganic salts and surfactants on cellulase hydrolysis have been studied, few studies have addressed the question of the mechanism behind the effects (Lou et al. 2013).

In the present study, pretreated wheat straw was enzymatically hydrolyzed in the presence of Tween 80 and $\mathrm{Fe}^{3+}$. The effects of surfactants and metal ions on enzymatic hydrolysis were evaluated by fluorescence spectra analysis, Fourier transform infrared (FTIR) spectroscopy, scanning electron microscopy (SEM), dynamic light scattering (DLS), enzymatic kinetics, and enzymatic activity analyses. This work may shed light on understanding the mechanism behind the effect of added cations and surfactants on enzymatic hydrolysis.

\section{EXPERMENTAL}

\section{Materials}

\section{Substrates and chemicals}

Pretreated wheat straw samples were collected from South China University of Technology in Guangzhou, China. They were ground into 40 to 60 mesh fractions and then treated with $\mathrm{NaOH}$ solutions and ultrasonication. The alkali and ultrasonic pretreatment protocols have been published in detail elsewhere (Wang et al. 2018). The compositions of the wheat straw samples (raw and pretreated) were determined using a published method (Van Soest 1963; Mo 2008), Table 1. Cellulose (46 FPU/g) was purchased from Beijing Solarbio Technology Corporation (Beijing, China), polyethylene glycol (PEG), polysorbate 80 (also called Tween 80 and by the IUPAC name polyoxyethylene (20) sorbitan monooleate), alkyl polyglycoside (APG), sodium $\alpha$-olefin sulfonate (AOS), cetylpyridinium chloride (CPC), dodecyl dimethyl tertiary amine oxide (OA), and dodecyl dimethyl betaine (BS-12), as well as all of the other chemicals used in this study, were obtained from Beijing Solarbio Technology Corporation (Beijing, China). 
Table 1. Composition of the Unpretreated and Pretreated Wheat Straw

\begin{tabular}{ccccc}
\hline Material & Cellulose (\%) & Hemicellulose (\%) & Lignin (\%) & Ash (\%) \\
\hline Raw Substrate & 40.40 & 24.50 & 13.00 & 7.20 \\
Alkali Pretreatment & 65.80 & 12.00 & 9.20 & 5.60 \\
Ultrasonic & 69.40 & 11.80 & 8.20 & 4.40 \\
Pretreatment & & &
\end{tabular}

\section{Methods}

Enzymatic hydrolysis

The enzymatic hydrolysis experiments were performed in an oscillator (IS-RSDA, Crystal Technology \& Industres, Inc., Dallas, TX, USA) at $150 \mathrm{rpm}$ at $50{ }^{\circ} \mathrm{C}$. The experiments were performed in duplicate, and the average values and standard deviations were calculated.

\section{Reducing sugar concentration measurements}

A colorimetric method, namely the DNS method, was employed to determine the reducing sugar concentration (Zhang and Yu 2017). The DNS reagent was reduced by the reducing sugar to generate a red-brown amino substance. The sugar concentration, which was proportional to the red-brown product concentration, was thereafter determined by the product absorbance using an ultraviolet-visible spectrophotometer (UV-3600, Shimadzu, National Tsing Hua University Technology Co., Ltd., Beijing, China) and a corresponding standard curve (Lu et al. 2004). The operation process was as follows: 0.5 $\mathrm{mL}$ enzymatic hydrolysis solution was added to a DNS solution; the mixtures were heated in boiling water bath for 5 minutes, followed by cooling and dilution. The OD value at $540 \mathrm{~nm}$ were determined for these samples, and the corresponding reducing sugar concentration values were obtained using standard curve of reducing sugar. The reducing sugar conversion rate was obtained with Eq. 1:

The reducing sugar conversion(\%)=reducing sugar produced $\times 100 /$ substrate

\section{SEM measurements}

The physical surface of the substrate after enzymatic hydrolysis was characterized by SEM (TESCAN VEGA II, S.R.O. Corporation, Brno, Czech Republic). The samples were mounted on an aluminum stub and coated with a thin layer of gold (JEOL JFC-1600 Auto Fine Coater, Tokyo, Japan) prior to analysis.

\section{FTIR measurements}

A FTIR spectrophotometer (Nicolet Is10 Thermo Scientific, Waltham, USA) was utilized to characterize the substrates on $\mathrm{KBr}$ disks. The spectra were obtained after an accumulation of 32 scans from $400 \mathrm{~cm}^{-1}$ to $4000 \mathrm{~cm}^{-1}$.

\section{DLS measurements}

Dynamic light scattering was performed on a Malvern Instrument Zetasizer Nano (Malvern, UK) equipped with a 22-mW He-Ne laser working at a wavelength of 632.8 $\mathrm{nm}$. The scattering angle was $173^{\circ}$.

Kinetics of the enzyme-catalyzed reactions

The enzymatic hydrolysis conditions were as follows: buffer $\mathrm{pH}$ of 4.8 , cellulase 
mass concentration of $3 \mathrm{~g} / \mathrm{L}, \mathrm{Fe}^{3+}$ mass concentration of $0.3 \mathrm{~g} / \mathrm{L}$, Tween 80 mass concentration of $5 \mathrm{~g} / \mathrm{L}$, and enzymatic hydrolysis time and temperature of $24 \mathrm{~h}$ and $50{ }^{\circ} \mathrm{C}$, respectively. The kinetic parameters of the enzyme-catalyzed reactions were obtained using a kinetics equation of the enzymatic reaction (Michaelis-Menten equation) (Eq. 2):

$$
V=V_{\max } \times s /\left(K_{\mathrm{m}}+s\right)
$$

where $s$ is the mass concentration of the substrate $(\mathrm{g} / \mathrm{L}), V$ is the starting rate $(\mathrm{g} /(\mathrm{L} \cdot \mathrm{min}))$, $V_{\max }$ is the maximum reaction rate $(\mathrm{g} /(\mathrm{L} \cdot \min ))$, and $K_{\mathrm{m}}$ is the Michaelisian constant $(\mathrm{g} / \mathrm{L})$. Enzymatic activity measurements

Enzymatic activity conditions were as follows: a cellulose mass concentration of $3 \mathrm{~g} / \mathrm{L}, \mathrm{Fe}^{3+} /$ Tween 80 ratio of 0.06 , and substrate-liquid mass fraction of $1.25 \%$. The substrate was the filter paper of Whatman No.1. Then the reducing sugar concentration was determined by the same method, and the enzyme activity was calculated by the reducing sugar content. The enzymatic activity of enzymatic hydrolysis was measured by the relative increase using Eq. 3:

$$
\text { The enzyme activity increase rate } / \%=\frac{\text { enzyme activity with } \mathrm{Fe}^{3+} / \text { Tween } 80 \text { - enzyme activity without additives }}{\text { enzyme activity without additives }} \times 100
$$

\section{Fluorescence spectra measurements}

An F-4600 spectrofluorometer (HITACHI, TOKYO, Japan) was employed to measure the fluorescence. The samples were excited at $280 \mathrm{~nm}$, and the emission spectrum of $300 \mathrm{~nm}$ to $650 \mathrm{~nm}$ was recorded.

\section{RESULTS AND DISCUSSION}

\section{Effect of Surfactants on Enzymatic Hydrolysis}

The effects of different surfactants on enzymatic hydrolysis in the presence of $\mathrm{Fe}^{3+}$ were investigated, Fig. 1. Based on previous research results (Wang et al. 2018), the $\mathrm{Fe}^{3+}$ concentration was selected as $0.3 \mathrm{~g} / \mathrm{L}$ to obtain the highest reducing sugar conversion rate. The surfactant concentration was $5 \mathrm{~g} / \mathrm{L}$. The enzymatic hydrolysis reactions were carried out using a thermostatic oscillator at $150 \mathrm{rpm}$ for $50 \mathrm{~h}$. The reducing sugar conversion rates were obtained by averaging two parallel measurements.

Figure 1 shows that the reducing sugar conversion rates in the presence of nonionic surfactants were higher than those with other types of surfactants. 


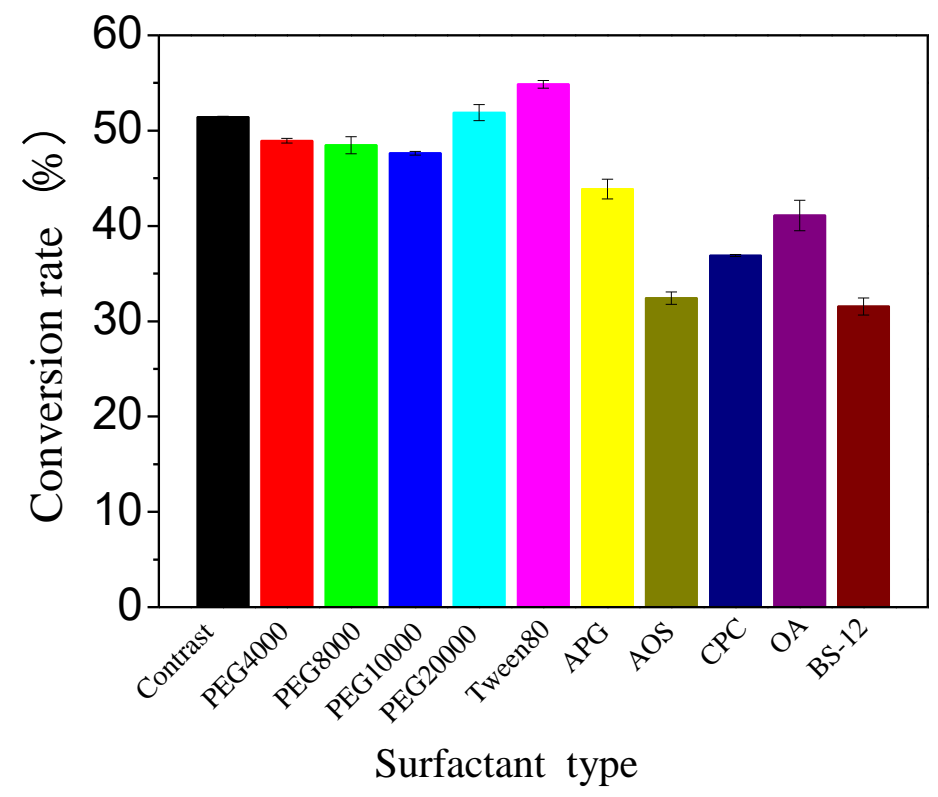

Fig. 1. Effect of the surfactants on enzymatic hydrolysis

Among all presented surfactants, only Tween 80 and PEG20000 increased the reducing sugar conversion rates compared with the contrast group without surfactant. As the molecular weight of PEG increased, the reducing sugar conversion rate decreased first and then increased. A maximum conversion rate of $54.9 \%$ was achieved with Tween 80 , which was $6.6 \%$ higher than that of $\mathrm{Fe}^{3+}$ alone.

\section{Effects of Different Metal lons on Enzymatic Hydrolysis}

The effects of various metal ions on enzymatic hydrolysis in the presence of Tween 80 at $50{ }^{\circ} \mathrm{C}$ are shown in Table 2 . The concentration of Tween 80 was $5 \mathrm{~g} / \mathrm{L}$, and the metal ion concentration was $0.3 \mathrm{~g} / \mathrm{L}$. All of the other reaction conditions remained the same.

Table 2. Effect of Different Metal lons on Enzymatic Hydrolysis with Tween 80 Solution

\begin{tabular}{ccccccc}
\hline Material & $\mathrm{NaCl}$ & $\mathrm{FeCl}_{2}$ & $\mathrm{FeCl}_{3}$ & $\mathrm{CoCl}_{2}$ & $\mathrm{MgCl}_{2}$ & $\mathrm{MgSO}_{4}$ \\
\hline $\begin{array}{c}\text { Conversion } \\
\text { Rate (\%) }\end{array}$ & 36.68 & 40.08 & 54.86 & 46.51 & 39.06 & 38.26 \\
\hline
\end{tabular}

Table 2 shows that $\mathrm{Fe}^{3+}$ is associated with the highest reducing sugar conversion rate, and therefore, it has the most positive effect on enzymatic hydrolysis. The conversion rate was approximately $55 \%$, which was $12.4 \%$ higher than that of Tween 80 alone. 


\section{Effect of $\mathrm{Fe}^{3+/}$ Tween 80 on Cellulase Hydrolysis}

Table 3 shows the effect of the ratio of $\mathrm{Fe}^{3+}$ and Tween 80 on enzymatic hydrolysis under the same reaction conditions.

Table 3. Effect of $\mathrm{Fe}^{3+} /$ Tween 80 on Cellulase Hydrolysis

\begin{tabular}{ccccccccc}
\hline $\begin{array}{c}\text { Rate of } \\
\mathrm{Fe}^{3+} / \text { Tween } \\
80\end{array}$ & Contrast & $\begin{array}{c}\text { Tween } \\
80\end{array}$ & 0.02 & 0.04 & 0.06 & 0.08 & 0.1 & $\mathrm{Fe}^{3+}$ \\
\hline $\begin{array}{c}\text { Conversion } \\
\text { Rate (\%) }\end{array}$ & 40.46 & 48.82 & 48.08 & 50.30 & 54.86 & 47.14 & 43.14 & 51.45 \\
\hline
\end{tabular}

The enzymatic hydrolysis system in the presence of additives was always associated with higher reducing sugar conversion rate compared with that of the contrast group. The highest enzymatic hydrolysis efficiency was obtained with a $\mathrm{Fe}^{3+} /$ Tween 80 ratio of 0.06 . The corresponding conversion rate was $54.9 \%$, which was $35.6 \%$ higher than that of the contrast group, $12.4 \%$ higher than that of pure Tween 80 , and $6.6 \%$ higher than that of pure $\mathrm{Fe}^{3+}$. Our results indicate that $\mathrm{Fe}^{3+}$ and Tween 80 have synergistic effect on enzymatic hydrolysis at the appropriate proportion.

\section{Surface Morphology}

The surface morphologies of different substrates, including non-pretreated, ultrasonically pretreated substrates, and substrates after four different enzymatic hydrolysis processes were studied with SEM. The differences among these four enzymatic hydrolysis conditions were whether $\mathrm{Fe}^{3+}$ and Tween 80 were added: (1) no additive; (2) $\mathrm{Fe}^{3+}$ only; (3) Tween 80 only; and (4) both $\mathrm{Fe}^{3+}$ and Tween 80 . Figure 2 shows SEM micrographs ( $800 \mathrm{x}$ and $1200 \mathrm{x})$ of these substrates, which revealed their surface structural changes.

The substrates were compact and rigid in Figs. $2 \mathrm{a}$ and $2 \mathrm{~b}$, but became rough and loose after being pretreated ultrasonically (Figs. 2c and 2d), which revealed that pretreatment increased the specific surface area of the substrates and therefore improved the enzymatic hydrolysis efficiency (Hendriks and Zeeman 2009). Figures 2 e through 21 show that pores were formed in the substrate after enzymatic hydrolysis. Importantly, the addition of both $\mathrm{Fe}^{3+}$ and Tween 80 to the hydrolysate was associated with a more porous substrate compared with the substrates treated by the hydrolysate containing just $\mathrm{Fe}^{3+}$ or Tween 80. This indicated that the effective combination of enzyme and substrate was improved, and the hydrolysis efficiency of the enzyme was enhanced. Therefore, the combination of $\mathrm{Fe}^{3+}$ and Tween 80 had a larger effect on cellulase hydrolysis. 

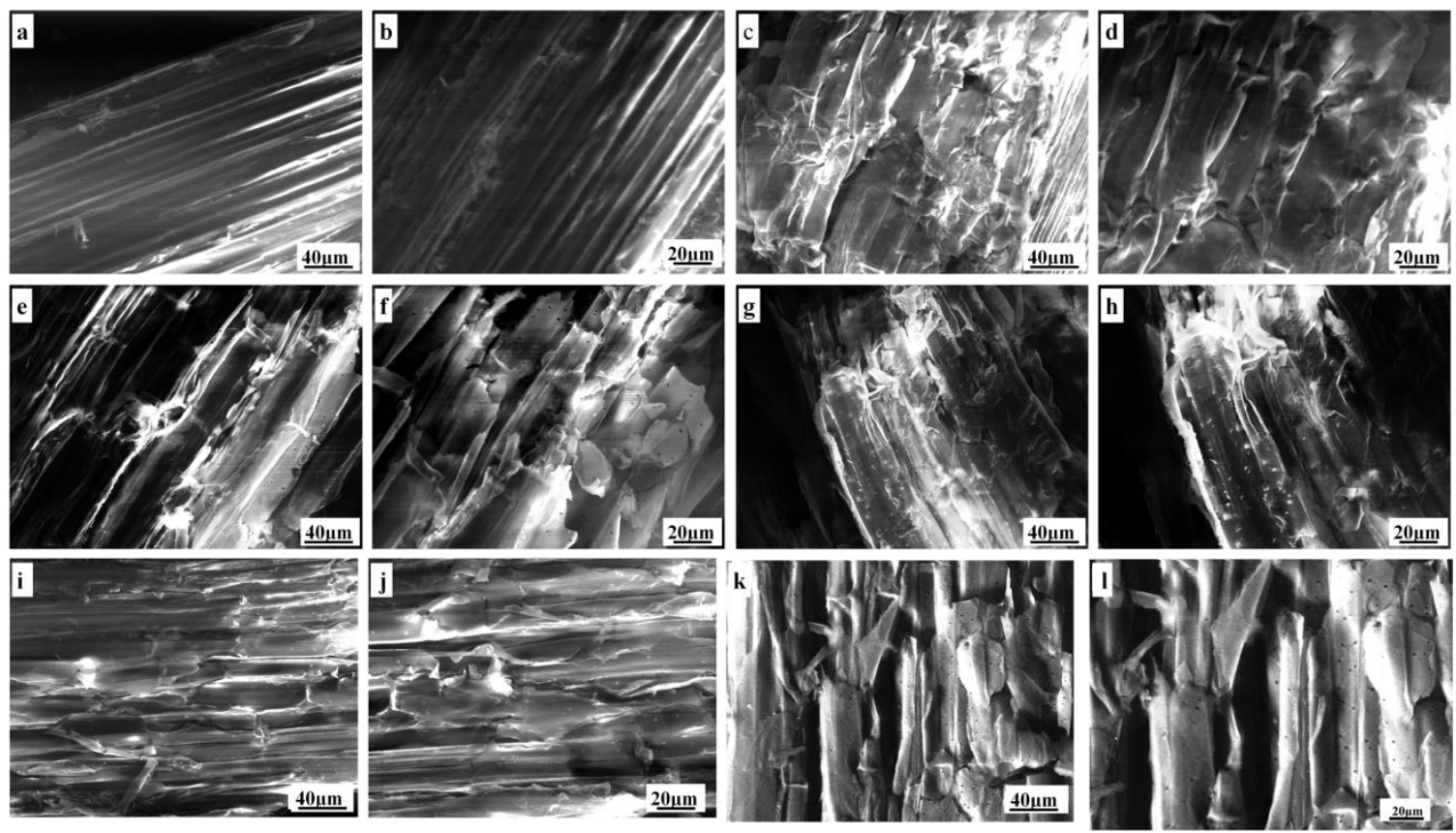

Fig. 2. SEM micrographs of the different substrates at different magnifications: non-pretreated substrate at $800 x$ (a) and 1200x (b); ultrasonically-pretreated substrate at $800 x$ (c) and 1200x (d); substrate after enzymatic hydrolysis without additives at $800 \mathrm{x}(\mathrm{e})$ and $1200 \mathrm{x}(\mathrm{f})$; substrate after enzymatic hydrolysis with $\mathrm{Fe}^{3+}$ at $800 \times(\mathrm{g})$ and $1200 \mathrm{x}(\mathrm{h})$; substrate after enzymatic hydrolysis with Tween 80 at $800 x$ (i) and 1200x (j); and substrate after enzymatic hydrolysis with $\mathrm{Fe} 3+$ l Tween 80 at $800 x(k)$ and $1200 x(\mathrm{l})$

\section{Infrared Spectrum Analysis}

The infrared spectra of different wheat straw substrates are shown in Fig. 3, and the relative intensities of the infrared absorption peaks at the optimum conditions are summarized in Table 4. The absorption peaks at approximately $3400 \mathrm{~cm}^{-1}$ were ascribed to intramolecular hydrogen bonds. Compared with the raw substrate, the relative peak intensities of the other substrates decreased, which revealed that the hydrogen bonds were destroyed after pretreatment and enzymatic hydrolysis. The minimum peak intensity was obtained in the case of $\mathrm{Fe}^{3+} /$ Tween 80 , which suggested that the addition of $\mathrm{Fe}^{3+} /$ Tween 80 strongly weakened the intramolecular hydrogen bonds.

The absorption peak at $1735 \mathrm{~cm}^{-1}$, which was ascribed to uronic ester and acetyl groups of the hemicellulose or ester linkages of the carboxylic group in the ferulic and pcoumaric acid present in the hemicellulose and lignin, appeared in the raw substrate, but it disappeared after pretreatment and enzymatic hydrolysis. This was probably because the ester bonds were chelated after pretreatment and enzymatic hydrolysis (Wang et al. 2018).

The absorption peaks at $1637 \mathrm{~cm}^{-1}$ were ascribed to absorbed water (Lu et al. 2004; Li et al. 2010). This peak split into two peaks and decreased after pretreatment and enzymatic hydrolysis (Fig. 3). Also, the relative intensity of this peak was higher for the substrate with Tween 80 (Table 4) compared to that without Tween 80 , indicating that the hydrophilic groups of Tween 80 and water combined during the adsorption of water by the cellulose. The relative intensity of the absorption peak at $1432 \mathrm{~cm}^{-1}$ remained basically the same in all cases, showing that the macromolecular structure of the cellulose did not change remarkably. The absorption peaks at $1164 \mathrm{~cm}^{-1}$ were ascribed to C-O-C groups of lignin. The intensities were lower when $\mathrm{Fe}^{3+}$ or Tween 80 was added compared with those of the raw and pretreated substrates (Table 4), confirming the decrease in the 
lignin content after hydrolysis. The absorption peak at approximately $1058 \mathrm{~cm}^{-1}$ to 1060 $\mathrm{cm}^{-1}$ was ascribed to stretching vibration of $\mathrm{C}=\mathrm{O}$ groups of lignin and hemicellulose. When $\mathrm{Fe}^{3+} /$ Tween 80 were added, this peak was weakened after enzymatic hydrolysis. The results showed that the content of hemicellulose and lignin decreased to a certain extent after the addition of $\mathrm{Fe}^{3+} /$ Tween 80 (Table 1) during enzymatic hydrolysis.

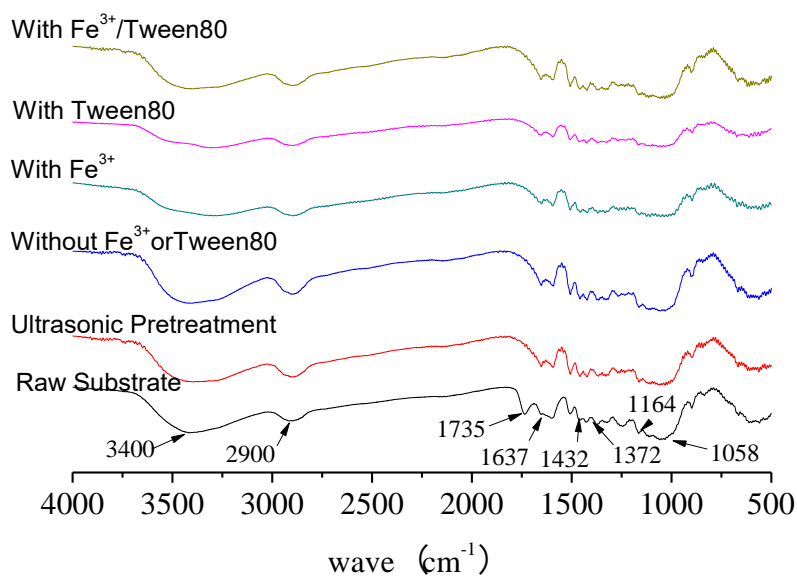

Fig. 3. FTIR spectra of the different substrates

Table 4. Relative Intensity of the Infrared Absorption Peaks of the Substrates

\begin{tabular}{ccccccc}
\hline $\begin{array}{c}\text { Wave } \\
\text { Number }\left(\mathrm{cm}^{-}\right.\end{array}$ & $\begin{array}{c}\text { Raw } \\
\text { Substrate }\end{array}$ & $\begin{array}{c}\text { Ultrasonic } \\
\text { Pretreatment }\end{array}$ & $\begin{array}{c}\text { Without } \mathrm{Fe}^{3+} \text { or } \\
\text { Tween } 80\end{array}$ & $\begin{array}{c}\text { With } \\
\mathrm{Fe}^{3+}\end{array}$ & $\begin{array}{c}\text { With } \\
\text { Tween } \\
80\end{array}$ & $\begin{array}{c}\text { With } \mathrm{Fe}^{3+/} \\
\text { Tween } 80\end{array}$ \\
\hline 3400 & 1.27 & 1.19 & 1.09 & 1.02 & 1.06 & 0.99 \\
2900 & 0.90 & 1.05 & 0.87 & 1.12 & 1.11 & 0.89 \\
1637 & 0.71 & 0.66 & 0.59 & 0.56 & 0.62 & 0.66 \\
1432 & 0.92 & 0.97 & 0.96 & 0.95 & 0.96 & 0.96 \\
1372 & 1.00 & 1.00 & 1.00 & 1.00 & 1.00 & 1.00 \\
1164 & 1.29 & 1.20 & 1.19 & 1.07 & 1.09 & 1.15 \\
$1058 \sim 1060$ & 1.50 & 1.29 & 1.28 & 1.13 & 1.12 & 1.24 \\
\hline
\end{tabular}

\section{Effect of $\mathrm{Fe}^{3+} /$ Tween 80 on the Particle Size of the Enzymatic Hydrolysis System}

The effects of $\mathrm{Fe}^{3+} /$ Tween 80 concentrations on hydrated particle size were measured by DLS, and the results are shown in Table 5 . 
Table 5. Particle Sizes of the Different $\mathrm{Fe}^{3+} / \mathrm{Tw}$ ween 80 Solutions

\begin{tabular}{|c|c|c|c|c|c|c|}
\hline $\begin{array}{c}\text { Ratio of } \\
\mathrm{Fe}^{3+} / \text { Tween } \\
80\end{array}$ & \multicolumn{2}{|c|}{$\begin{array}{c}\text { Particle Sizes of Fe } \\
\text { Tween 80 Solution } \\
\text { Before Reaction }(\mathrm{nm})\end{array}$} & $\begin{array}{c}\text { Particle Sizes of } \mathrm{Fe}^{3+} \\
\text { Tween 80 With } \\
\text { Cellulase Solution } \\
\text { Before Reaction }(\mathrm{nm})\end{array}$ & $\begin{array}{c}\text { Particle Sizes of Fe } \\
\text { Tween 80 Solution After } \\
\text { Reaction (nm) }\end{array}$ \\
\hline 0 & \multicolumn{2}{|c|}{11.59} & \multicolumn{2}{c|}{11.66} & \multicolumn{2}{c|}{13.89} \\
\hline 0.02 & 10.10 & 220.19 & 11.70 & 295.31 & 11.70 & 220.19 \\
\hline 0.04 & 10.10 & 220.19 & 10.10 & 295.31 & 11.70 & 164.18 \\
\hline 0.06 & 10.10 & 255.00 & 11.70 & 396.06 & 11.70 & 190.14 \\
\hline 0.08 & 10.10 & 255.00 & 11.70 & 458.67 & 11.70 & 190.14 \\
\hline 0.10 & 10.10 & 295.31 & 11.70 & 458.67 & 13.03 & 164.18 \\
\hline 1 & \multicolumn{2}{|c|}{531.17} & \multicolumn{2}{|c|}{824.99} & \multicolumn{2}{c|}{1106.44} \\
\hline
\end{tabular}

In pure Tween 80 or $\mathrm{Fe}^{3+}$ aqueous solution (ratio of $\mathrm{Fe}^{3+} /$ Tween 80 equals to 0 or 1 ), only one peak was obtained. For cellulose solution in the presence of only Tween 80 , the particle sizes changed little before and after reaction. However, when the ratio of $\mathrm{Fe}^{3+} /$ Tween 80 was 1 (only $\mathrm{Fe}^{3+}$ ), the particle sizes varied greatly before and after the reaction. In particular, the particle sizes became larger with added cellulase, which indicated that the conformation of the cellulase changed greatly with the addition of $\mathrm{Fe}^{3+}$.

Two peaks were observed in the presence of both Tween 80 and $\mathrm{Fe}^{3+}$. The peak centered at approximately $10 \mathrm{~nm}$ to $13 \mathrm{~nm}$ remained the same in all of the cases. As the $\mathrm{Fe}^{3+} /$ Tween 80 ratio increased, the other peak shifted towards larger values. For fixed $\mathrm{Fe}^{3+} /$ Tween 80 ratio, this peak shifted towards larger values with the addition of cellulase, but smaller values after the hydrolysis reaction. The results suggested that the added $\mathrm{Fe}^{3+} /$ Tween 80 interacted with the cellulase and substrate to some extent, which facilitated contact between the cellulase and cellulose, and improved the stability of the cellulase.

\section{Effect of $\mathrm{Fe}^{3+} /$ Tween $\mathbf{8 0}$ on the Enzymatic Activity}

The effects of $\mathrm{Fe}^{3+} /$ Tween 80 on the enzymatic activities are presented in Fig. 4.

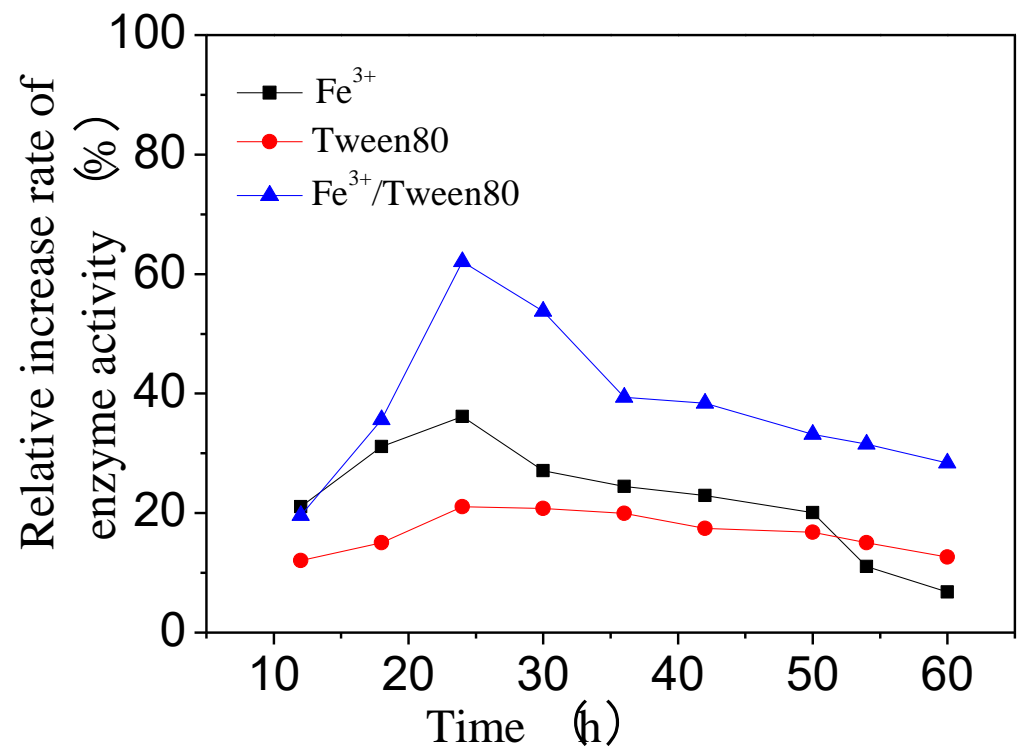

Fig. 4. Effect of $\mathrm{Fe}^{3+} / \mathrm{T}$ ween 80 on the enzyme activity 
The relative enzymatic activity increase rate, defined in Eq. 3, was used to reflect the effects of additives on enzymatic activity. The relative enzymatic activity increase rates in Fig. 4 were all greater than zero, which indicated that both $\mathrm{Fe}^{3+}$ and Tween 80 promoted enzymatic activity. Metal ions are activators of cellulose, which can change the conformation of cellulose and reduce non-productive enzyme adsorption (Li et al. 2009). Surfactants may adsorb onto the substrate surface and reduce ineffective adsorption of the enzyme and substrate; therefore, surfactants can also increase enzyme activity (Park et al. 1992; Dizhbite et al. 1999; Eriksson et al. 2002; Lou et al. 2013). Notably, the relative enzymatic activity increase rate of the $\mathrm{Fe}^{3+} /$ Tween 80 solution was higher than that of $\mathrm{Fe}^{3+}$ or Tween 80 alone, which indicated that $\mathrm{Fe}^{3+}$ and Tween 80 had a good synergistic effect.

\section{Effect of $\mathrm{Fe}^{3+} / \mathrm{Tween} \mathbf{8 0}$ on the Enzyme Kinetics}

The effect of $\mathrm{Fe}^{3+} /$ Tween 80 on the enzyme kinetics is shown in Fig. 5 and Table 6. For the sake of comparison, a negative control experiment without $\mathrm{Fe}^{3+}$ or Tween 80 was performed. The ratio of $\mathrm{Fe}^{3+} /$ Tween 80 was fixed at 0.06 for the other groups. Although both $\mathrm{Fe}^{3+}$ and Tween 80 increased the $V_{\max }$ and $K_{\mathrm{m}}$, the increases with Tween 80 were larger than with $\mathrm{Fe}^{3+}$. Although the $V_{\max }$ and $K_{\mathrm{m}}$ values for $\mathrm{Fe}^{3+} /$ Tween 80 were a bit less compared with the groups containing just $\mathrm{Fe}^{3+}$ or Tween 80 , they were still much larger than those of the control group. The $V_{\max }$ value increased by $30.65 \%$, and the $K_{\mathrm{m}}$ value increased by $4.62 \mathrm{~g} / \mathrm{L}$.

The $K_{\mathrm{m}}$ value was inversely proportional to the affinity between substrate and enzyme. Added $\mathrm{Fe}^{3+}$ and Tween 80 occupied the adsorption sites of the substrate and reduced ineffective sorption of the enzyme (Liu et al. 2010; Lou et al. 2014a; Lou et al. 2014b; Akimkulova et al. 2016). Therefore, the enzyme activity and enzymatic intermediates of dissociation were increased. This effect promoted the positive reaction direction and was beneficial to the enzymatic reaction (Zhang et al. 2010).

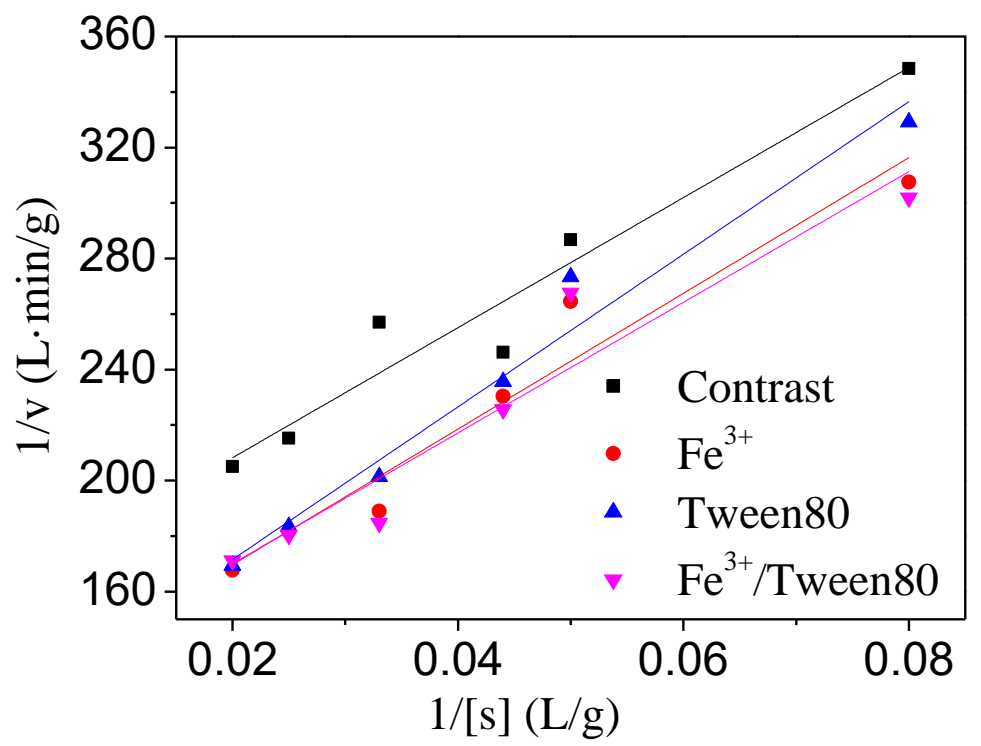

Fig. 5. Effect of $\mathrm{Fe}^{3+} / \mathrm{Tw}$ ween 80 on the enzyme kinetics 
Table 6. Effect of $\mathrm{Fe}^{3+} / \mathrm{T}$ ween 80 on the Enzyme Kinetics Parameters

\begin{tabular}{ccccc}
\hline Sample & Millimeter Equation & $V_{\max }(\mathrm{g} / \mathrm{L} / \mathrm{min})$ & $K_{\mathrm{m}}(\mathrm{g} / \mathrm{L})$ & $R^{2}$ \\
\hline Control & $y=2343.4 x+161.35$ & 0.0062 & 14.52 & 0.9441 \\
Tween 80 & $y=2749.3 x+116.59$ & 0.0086 & 23.58 & 0.9741 \\
$\mathrm{Fe}^{3+}$ & $y=2444.8 x+120.77$ & 0.0083 & 20.24 & 0.9525 \\
$\mathrm{Fe}^{3+} /$ Tween 80 & $y=2353.9 x+123.00$ & 0.0081 & 19.14 & 0.9245 \\
\hline
\end{tabular}

\section{Fluorescence Spectrum Analysis}

The effect of $\mathrm{Fe}^{3+} /$ Tween 80 was also studied by fluorescence spectrum, and the results are shown in Fig. 6. The excitation wavelength was set at $280 \mathrm{~nm}$, which is the maximum absorption wavelength of cellulose. A wavelength range of $300 \mathrm{~nm}$ to $650 \mathrm{~nm}$ was monitored for the fluorescence emission, which reflected the molecular conformation transformation of the enzyme (Wu et al. 2008). The maximum in fluorescence spectra at $346.4 \mathrm{~nm}(24 \mathrm{~h})$ and $344.8 \mathrm{~nm}(36 \mathrm{~h})$ without $\mathrm{Fe}^{3+} /$ Tween 80 were the emission of tryptophan and tyrosine in the cellulase (Podestá and Plaxton 2003; Sułkowska et al. 2004). Previously, it has been found that the peak shifted to $392.4 \mathrm{~nm}(24 \mathrm{~h})$ and 358.2 $\mathrm{nm}(36 \mathrm{~h})$ with the addition of Tween 80 and shifted to $435.9 \mathrm{~nm} \mathrm{(24} \mathrm{h)} \mathrm{and} 439.4 \mathrm{~nm}$ (36 h) with the addition of $\mathrm{Fe}^{3+}$ (Wang et al. 2018). In the presence of both $\mathrm{Fe}^{3+}$ and Tween 80 , the peak shifted to $424.8 \mathrm{~nm}$ and $446.4 \mathrm{~nm}$ at $24 \mathrm{~h}$ and $36 \mathrm{~h}$, respectively, which was a longer wavelength. The reason was probably that the presence of $\mathrm{Fe}^{3+}$ and Tween 80 caused great transformation in enzyme conformation. The fluorescence intensities were remarkably reduced because of the fluorescence quenching effect caused by the $\mathrm{Fe}^{3+}$ and Tween 80 interacted with the cellulase molecules.

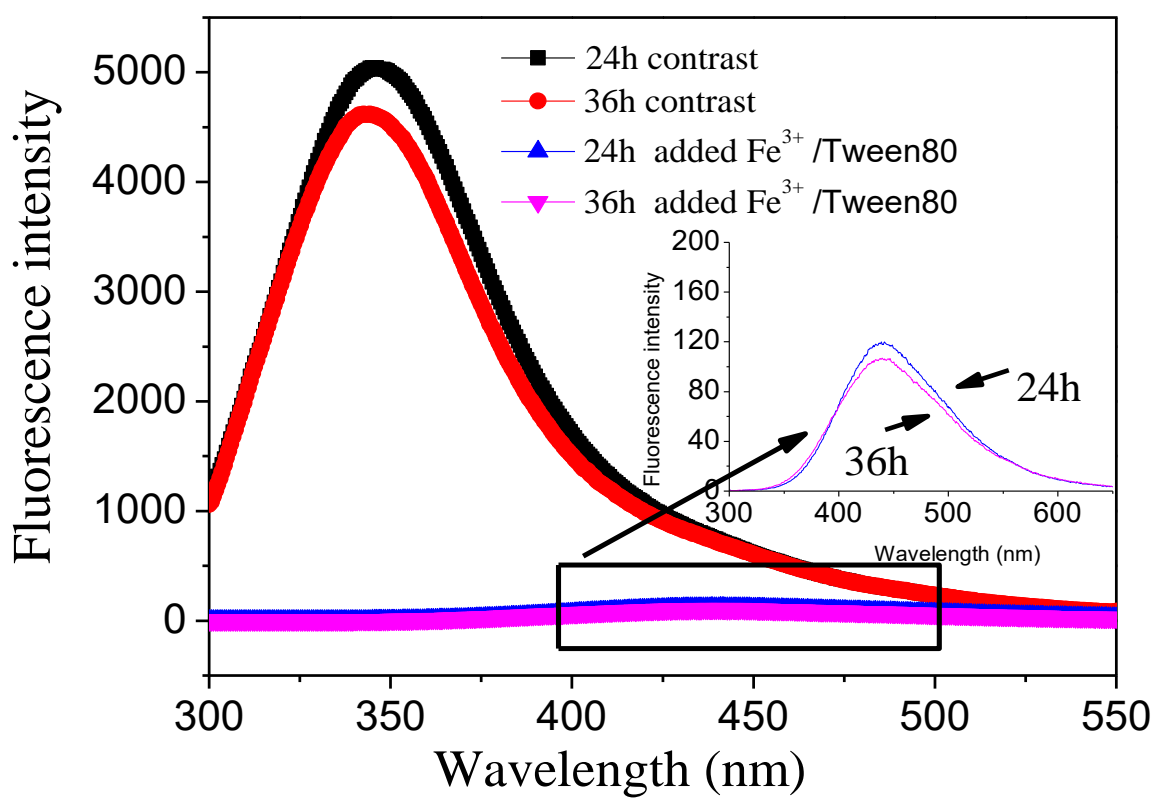

Fig. 6. Fluorescence spectrum with $\mathrm{Fe}^{3+} / \mathrm{T}$ ween 80 


\section{CONCLUSIONS}

1. The combination of $\mathrm{Fe}^{3+}$ and Tween 80 in appropriate proportions resulted in a good synergistic effect on the enzymatic hydrolysis of pretreated wheat straw.

2. The addition of $\mathrm{Fe}^{3+} / \mathrm{Tween} 80$ instead of single additives resulted in more porosity in the substrates. The relative intensities of the infrared absorption peaks for systems containing $\mathrm{Fe}^{3+} /$ Tween 80 were also different from those without additives. The relative enzymatic activity increase rate of the enzymatic hydrolysis with $\mathrm{Fe}^{3+} /$ Tween 80 was higher than that with $\mathrm{Fe}^{3+}$ or Tween 80 alone.

3. The intensity of the fluorescence spectrum decreased with added $\mathrm{Fe}^{3+} /$ Tween 80 , and the maximum absorption wavelength shifted towards a longer wavelength. The presence of $\mathrm{Fe}^{3+}$ and Tween 80 led to great conformational changes.

\section{ACKNOWLEDGMENTS}

This work was funded by the National Key R\&D Program of China (No 2017YFB0308701), the National Natural Science Foundation of China (Nos. 21203005 and 21676003), Beijing Municipal Science and Technology Project (D17110500190000), and the postgraduate research capacity improvement program in 2018.

\section{REFERENCES CITED}

Akimkulova, A., Zhou, Y., Zhao, X., and Liu, D. (2016). "Improving the enzymatic hydrolysis of dilute acid pretreated wheat straw by metal ion blocking of nonproductive cellulase adsorption on lignin," Bioresource Technol. 208, 110-116. DOI: 10.1016/j.biortech.2016.02.059

Börjesson, J., Engqvist, M., Sipos, B., and Tjerneld, F. (2007). "Effect of poly(ethylene glycol) on enzymatic hydrolysis and adsorption of cellulase enzymes to pretreated lignocelluloses," Enzyme Microb. Tech. 41(1-2), 186-195. DOI: 10.1016/j.enzmictec.2007.01.003

Chen, Y., Dong, B., Qin, W., and Xiao, D. (2010). "Xylose and cellulose fractionation from corncob with three different strategies and separate fermentation of them to bioethanol," Bioresource Technol. 101(18), 6994-6999. DOI:

10.1016/j.biortech.2010.03.132

Dizhbite, T., Zakis, G., Kizima, A., Lazareva, E., Rossinskaya, G., Jurkjane, V., Telysheva, G., and Viestures, U. (1999). "Lignin - A useful bioresource for the production of sorption-active materials," Bioresource Technol. 67(3), 221-228. DOI: 10.1016/S0960-8524(98)80004-7

Eriksson, T., Börjesson, J., and Tjerneld, F. (2002). "Mechanism of surfactant effect in enzymatic hydrolysis of lignocellulose," Enzyme Microb. Technol. 31(3), 353-364. DOI: 10.1016/S0141-0229(02)00134-5

Fang, X., Qin, Y., Li, X., Wang, L., Wang, T., Zhu, M., and Qu, Y. (2010). "Progress on cellulase and enzymatic hydrolysis of lignocellulosic biomass," Chinese Journal of Biotechnology 26(7), 864-869. 
Hendriks, A. T. W. M., and Zeeman, G. (2009). "Pretreatments to enhance the digestibility of lignocellulosic biomass," Bioresource Technol. 100(1), 10-18. DOI: 10.1016/j.biortech.2008.05.027

Kamireddy, S. R., Li, J., Tucker, M., Degenstein, J., and Ji, Y. (2013). "Effects and mechanism of metal chloride salts on pretreatment and enzymatic digestibility of corn stover," Ind. Eng. Chem. 52(5), 1775-1782. DOI: 10.1021/ie3019609

Kang, K. E., Park, D.-H., and Jeong, G.-T. (2013). "Effects of $\mathrm{NH}_{4} \mathrm{Cl}$ and $\mathrm{MgCl}_{2}$ on pretreatment and xylan hydrolysis of miscanthus straw," Carbohyd. Polym. 92(2), 1321-1326. DOI: 10.1016/j.carbpol.2012.10.019

Kristensen, J. B., Börjesson, J., Bruun, M. H., Tjerneld, F., and Jørgensen, H. (2007). "Use of surface active additives in enzymatic hydrolysis of wheat straw lignocellulose," Enzyme Microb. Tech. 40(4), 888-895. DOI: 10.1016/j.enzmictec.2006.07.014

Li, D.-y., Gong, D.-c., Tian, Y.-h., and Yu, Y. (2009). "Study on the effects of metal ions on cellulase activity," Liquor-making Science and Technology 6, 40-42. DOI: 10.13746/j.njkj.2009.06.001

Li, D.-y., Tian, Y.-h., and Gong, D.-c. (2015). "Effects of metal ion on the hydrolysis of steam-exploded straw by cellulase," Hubei Agricultural Sciences 54(3), 546-549.

Li, M.-F., Fan, Y.-M., Xu, F., Sun, R.-C., and Zhang, X.-L. (2010). “Cold sodium hydroxide/urea based pretreatment of bamboo for bioethanol production: Characterization of the cellulose rich fraction," Ind. Crop. Prod. 32(3), 551-559. DOI: 10.1016/j.indcrop.2010.07.004

Li, Y.-s. (2007). "Research and thought of the development of biomass energy source industry," Journal of Anhui Agricultural Science 35(24), 7562-7563.

Liu, C., and Wyman, C. E. (2006). "The enhancement of xylose monomer and xylotriose degradation by inorganic salts in aqueous solutions at $180{ }^{\circ} \mathrm{C}, "$ Carbohyd. Res. 341(15), 2550-2556. DOI: 10.1016/j.carres.2006.07.017

Liu, H., Zhu, J. Y., and Fu, S. Y. (2010). "Effects of lignin-metal complexation on enzymatic hydrolysis of cellulose," J. Agr. Food Chem. 58(12), 7233-7238. DOI: 10.1021/jf1001588

Liu, L., Sun, J., Cai, C., Wang, S., Pei, H., and Zhang, J. (2009a). “Corn stover pretreatment by inorganic salts and its effects on hemicellulose and cellulose degradation," Bioresource Technol. 100(23), 5865-5871. DOI: 10.1016/j.biortech.2009.06.048

Liu, L., Sun, J., Li, M., Wang, S., Pei, H., and Zhang, J. (2009b). "Enhanced enzymatic hydrolysis and structural features of corn stover by $\mathrm{FeCl}_{3}$ pretreatment," Bioresource Technol. 100(23), 5853-5858. DOI: 10.1016/j.biortech.2009.06.040

Liu, Y., Sun, J., Pei, H., Liu, L., and Duan, K. (2011). "Research progress on improving the efficiency of enzymatic hydrolysis of lignocellulose," China Brewing 30(5), 1620.

Lou, H., Wang, M., Lai, H., Lin, X., Zhou, M., Yang, D., and Qiu, X. (2013). "Reducing non-productive adsorption of cellulase and enhancing enzymatic hydrolysis of lignocelluloses by noncovalent modification of lignin with lignosulfonate," Bioresource Technol. 146, 478-484. DOI: 10.1016/j.biortech.2013.07.115

Lou, H.,Zhou, H., Li, X., Wang, M., Zhu, J. Y., and Qiu, X. (2014a). "Understanding the effects of lignosulfonate on enzymatic saccharification of pure cellulose," Cellulose 21(3), 1351-1359.

Lou, H., Wu, S., Li, X., Lan, T., Yang, D., Pang, Y., Qiu, X., Li, X., and Huang, J. (2014b). "Improving rheology and enzymatic hydrolysis of high-solid corncob 
slurries by adding lignosulfonate and long-chain fatty alcohols," Journal of Agricultural and Food Chemistry 62(33), 8430-8436.

Lu, J., Shi, S. L., Xing, X. G., and Yang, R. N. (2004). "Pretreatment of lignocellulose by sodium hydrolysis," Journal of Cellulose Science and Technology 12(1), 1-6.

Luo, P., and Liu, Z. (2011). "Enzymatic hydrolysis of wheat straw cooperated with tween-20," Journal of South China Agricultural University 31(1), 55-59.

Mo, D. (2008). Study on the Effect of Surfactants on Enzymatic Hydrolysis of Rice Straw, Master's Thesis, Hunan University, Changsha, China.

Monschein, M., Reisinger, C., and Nidetzky, B. (2014). "Dissecting the effect of chemical additives on the enzymatic hydrolysis of pretreated wheat straw," Bioresource Technol. 169, 713-722. DOI: 10.1016/j.biortech.2014.07.054

Paljevac, M., Primožič, M., Habulin, M., Novak, Z., and Knez, Ž. (2007). "Hydrolysis of carboxymethyl cellulose catalyzed by cellulase immobilized on silica gels at low and high pressures," J. Supercrit. Fluid. 43(1), 74-80. DOI: 10.1016/j.supflu.2007.05.006

Park, J. W., Takahata, Y., Kajiuchi, T., and Akehata, T. (1992). "Effects of nonionic surfactant on enzymatic hydrolysis of used newspaper," Biotechnol. Bioeng. 39(1), 117-120. DOI: 10.1002/bit.260390117

Podestá, F. E., and Plaxton, W. C. (2003). "Fluorescence study of ligand binding to potato tuber pyrophosphate-dependent phosphofructokinase: Evidence for competitive binding between fructose-1,6-bisphosphate and fructose-2,6bisphosphate," Arch. Biochem. Biophys. 414(1), 101-108. DOI: 10.1016/S00039861(03)00157-7

Ren, T.-b., Yin, S.-y., Ma, X.-q., Zhang, L.-1., Su, Y., and Song, A.-d. (2012). "The effect of chemical inducers on enzymatic hydrolysis of rice straw," Journal of AgroEnvironment Science 31(1), 206-211.

Sułkowska, A., Równicka, J., Bojko, B., Poźycka, J., Zubik-Skupień, I., and Sułkowski, W. (2004). "Effect of guanidine hydrochloride on bovine serum albumin complex with antithyroid drugs: Fluorescence study," J. Mol. Struct. 704(1-3), 291-295. DOI: 10.1016/j.molstruc.2003.12.065

Sun, F., Lou, X., Hong, J., Gu, Q., Chen, X., Cai, Y., and Liao, X. (2011). "Enhanced enzymatic hydrolysis of lignocelluloses by non-ionic surfactant," Chemical Industry and Engineering Progress 30(12), 2719-2723.

Tu, M., and Saddler, J. N. (2010). "Potential enzyme cost reduction with the addition of surfactant during the hydrolysis of pretreated softwood," Appl. Biochem. Biotech. 161(1-8), 274-287. DOI: 10.1007/s12010-009-8869-4

Van Soest, P. J. (1963). "Use of detergents in the analysis of fibrous feeds. 2. A rapid method for the determination of fiber and lignin," J. Assoc. Off. Ana. Chem. 46, 546551.

Wang, S., Lv, M., Yang, J., Zhou, Y., and Xu, B. (2018). "Effects and mechanism of metal ions on enzymatic hydrolysis of wheat straw after pretreatment," BioResources 13(2), 2617-2631. DOI: 10.15376/biores.13.2.2617-2631

Wu, B., Wang, L. S., and Gao, P. J. (2008). "Study on the molecular configuration and conformation changes of nitrobenzene fiber two glycoside (PNPC) binding to exotangent cellulase I (CBHI)," Science in China Press 38(6), 527-535.

Zhang, J., and Yu, Y. (2017). "Study on the interaction between cellulase and surfactants," Tenside Surfact. Det. 54(3), 206-213. DOI: 10.3139/113.110493

Zhang, M., Su, R., Qi, W., and He, Z. (2010). "Enhanced enzymatic hydrolysis of lignocellulose by optimizing enzyme complexes," Appl. Biochem. Biotech. 160(5), 1407-1414. DOI: 10.1007/s12010-009-8602-3 
Zhao, J., Zhang, H., Zheng, R., Lin, Z., and He, H. (2011). "The enhancement of pretreatment and enzymatic hydrolysis of corn stover by $\mathrm{FeSO}_{4}$ pretreatment," Biochem. Eng. J. 56(3), 158-164. DOI: 10.1016/j.bej.2011.06.002

Article submitted: October 9, 2018; Peer review completed: December 30, 2018; Revised version received and accepted: January 7, 2019; Published: January 14, 2019.

DOI: 10.15376/biores.14.1.1653-1667 